\title{
Dentes intencionalmente modificados e etnicidade em cemitérios do Brasil Colônia e Império
}

\author{
Andersen Liryo* \\ Sheila Mendonça de Souza ** \\ Della Collins Cook***
}

LIRYO, A.; SOUZA, S.M; COOK, D.C. Dentes intencionalmente modificados e etnicidade em cemitérios do Brasil Colônia e Império. R. Museu Arq. Etn., São Paulo, n. 21, p. 315-334, 2011.

Resumo: A modificação intencional dos dentes foi muito difundida na África, vindo com escravos para a América. No Brasil foram encontradas em alguns sítios arqueológicos, sendo aqui estudadas em dois cemitérios históricos do Brasil: Pretos Novos, no Rio de Janeiro (único cemitério de um mercado de escravos na América), e cemitérios da antiga Sé de Salvador. Entre 570 dentes (30 indivíduos) dos Pretos Novos foram encontrados 13 dentes modificados. Entre 3181 dentes da Sé (62 enterros primários do séc. XVIII, e número indeterminado de re-deposições de outros períodos) foram encontrados 122 dentes modificados. Sua análise resultou em 13 tipos de modificações, a maior parte nos incisivos centrais superiores, e 10 tipos de arcos dentários modificados, evidenciando-se a técnica de percussão e lascamento dos dentes na maior parte dos casos. $\mathrm{O}$ achado de diferentes estilos de modificações sugere diferentes origens geográficas para os escravos do Rio e Salvador, o que é consistente com os dados históricos. No adro da Sé, a proximidade de enterros com modificações dentárias semelhantes sugere laços étnicos ou sociais, talvez de parentesco, entre os mortos.

Palavras-chave: Modificação dentária intencional - Escravidão - Arqueologia histórica - Bioarqueologia - Brasil - África.

\section{Introdução}

$\mathrm{M}$ odificações intencionais dos dentes têm sido usadas como marcadores de etnicidade por diversos povos em todo o

${ }^{*}$ ) Departamento de Antropologia, Museu Nacional, UFR (Brasil). <liryo@hotmail.com>

${ }^{(* *)}$ Departamento de Endemias Samuel Pessoa, Escola Nacional de Saúde Pública/Fiocruz (Brasil).〈sferraz@ensp.fiocruz.br> mundo. Feitas com diferentes técnicas e obedecendo a diferentes padrões principalmente nos incisivos superiores, são encontradas em muitos grupos africanos da região hoje correspondente a países como África do Sul, Angola, Congo, Kenya, Nigéria, Moçambique, Somália, Sudão,

$\left.{ }^{(* * *}\right)$ Departamento de Antropologia, Universidade de Indiana (EUA).<cook@indiana.edu> 
Tanzânia e Uganda, e em alguns lugares continuam a ser praticadas (Almeida 1953; Amaral 1968; Pereira Filho 1968; Halestrap 1971; Jones 1992; Singer 1953; Morris 1998; Kabiru 2009; Rodd \& Davidson 2000; Fabian \& Mumghamba 2007).

O tráfico de escravos para a América ajudou a dispersar este traço cultural, o que é comprovado, entre outros documentos, pelos registros de compra e venda de escravos e pelos anúncios para captura de africanos que fugiam do cativeiro (Freyre 1957; Handler et al. 1982; Schwarcz 1996; Amantino 1996). Alguns padrões de modificações dentárias intencionais podem ser observados em mais de uma etnia africana, podendo inclusive ser modificados por iniciativa e criatividade individual (Almeida 1953), o que dificulta a associação da maior parte dos padrões a etnias africanas específicas. Trata-se de uma prática cultural realizada com intenções iniciatórias, estéticas, religiosas e outras, mas não com a intenção de "mutilar". Por esta razão, no presente trabalho os autores não utilizam o termo "mutilação dentária", preferindo o uso da expressão "modificação intencional" dos dentes.

A partir de trabalhos iniciais na Flórida e na ilha de Granada, na América Central (Ortner 1966; Stewart \& Groome 1968), e dos estudos de esqueletos exumados de cemitério de africanos e afro-descendentes nos Estados Unidos (Blakey 2001) e em Barbados (Handler et al. 1982; Handler 1994), passou-se a afirmar a convicção de que, ao menos na América do Norte, o uso da modificação intencional dos dentes não teria se reproduzido entre os afro-descendentes. Entre outras razões, a perda deste traço cultural teria se dado porque os recém-chegados e seus descendentes, sem os vínculos e contexto culturais originais, teriam perdido as referências culturais e sociais necessárias à manutenção das mesmas. Outra razão para o abandono desta prática teria sido a sua evitação voluntária, já que os portadores das marcas étnicas no corpo seriam mais facilmente identificados pela sua condição social ou origem, aumentando o risco de segregação e re-captura (Handler et al. 1982: 307). Desse modo, pelo menos para a bioarqueologia dos Estados Unidos o achado de dentes modificados passou a ser indicativo bioarqueológico da presença de africanos de origem. Chama atenção a frequência de casos nos sítios coloniais na região do mar do Caribe (Tiesler 2002: 280-281).

No Brasil diferentes tipos de modificações dentárias também ocorrem associados aos escravos africanos que começaram a ser trazidos a partir do século XVI. Seus padrões mudaram ao longo do tempo, com a mudança de regiões de origem dos escravos, e o número de indivíduos portadores desta característica deve ter aumentado entre o final do século XVIII e o início do século XIX, com o significativo aumento do número de cativos trazidos pelos navios negreiros. Diferentes etnias africanas que foram escravizadas faziam uso de modificações intencionais dos dentes, por isso a relação entre as modificações encontradas aqui e as prováveis etnias ou culturas africanas originais é um tema de estudo.

Ao contrário do que parece ter ocorrido na maior parte da América, a prática de modificações nos dentes no Brasil foi incorporada por não cativos e populações do interior, saindo dos limites das senzalas. Fixou-se como prática regional, aparentemente relacionada a valores estéticos, principalmente ao longo do rio São Francisco (Netto 1882: 47), ainda sendo observada na primeira metade do século XX entre os sertanejos brasileiros (Amaral 1968 [1931]: 189-190). Paradoxalmente, apesar de ter sido adotada inclusive por grupos indígenas como os Tenetehara (Lima 1954: 12-13), não tem sido referida em grupos afro-descendentes de resistência cultural, tais como os quilombolas.

Ainda que tenha persistido no Brasil após o fim do tráfico negreiro, essa prática foi pouco valorizada como objeto de estudo antropológico, sendo motivo de poucos trabalhos (Netto 1882; Lima 1954; Cunha 1968a , 1968b; 1973; Nesi 1968; 1969; Nesi e Queiroz 1968; Pereira Filho 1968; Amaral 1968; Liryo et al. 2001; Machado 2006). No Brasil também tem sido feita associação entre a presença deste traço cultural e a identidade africana de esqueletos humanos 
achados em sítios históricos, ainda que sua persistência em populações brasileiras esteja comprovada.

Em Cuba há relato de que as modificações intencionais dos dentes por influência africana também tenham persistido após o século XVIII (Ortiz 1929: 17). Aquela área caribenha de economia escravista funcionou como quarentena e entreposto de escravos destinados à América do Norte, concentrando grande número de africanos longe das pressões sociais vigentes nos Estados Unidos. Embora os exemplos arqueológicos cubanos permaneçam controversos (Tiesler 2002: 280-281), ali podem ter havido condições diferentes das norte-americanas, permitindo a manutenção de práticas tradicionais africanas. Assim sendo, a persistência de modificações intencionais dos dentes aqui, como na América Central, após o período escravista, obriga a questionar a utilidade deste traço cultural enquanto marcador de origem africana.

No Brasil, os sítios arqueológicos contendo enterros de africanos e seus descendentes têm sido pouco estudados, principalmente do ponto de vista bioarqueológico. No presente trabalho são analisadas as evidências sobre modificações dentárias encontradas em remanescentes esqueléticos humanos provenientes de dois sítios (Fig. 1) datados dos séculos XVII a XIX: o cemitério dos Pretos Novos, no Rio de Janeiro (Machado 2006; Pereira 2007), e o cemitério da antiga Sé de Salvador, na Bahia (Etchevarne et al. 1999; Liryo et al. 2001; Tavares 2006). Em ambos está historicamente registrado o enterro de escravos africanos, mas também de afro-descendentes e outros brasileiros de nível sócio-econômico inferior. Nas interpretações iniciais sobre ambos os sítios históricos, as modificações intencionais foram valorizadas para confirmar a presença de indivíduos não locais, ou seja, de africanos.

O presente estudo visa aprofundar o olhar sobre esta prática cultural, a partir dos achados acima referidos, e deverá contribuir para a compreensão da presença arqueológica deste traço cultural no Brasil, e seu valor como indicador étnico e de origem africana.

\section{As séries arqueológicas e seus contextos}

\section{O Cemitério dos Pretos Novos}

O cemitério dos Pretos Novos foi achado acidentalmente, em 1996. Quando da reforma em uma residência da Gamboa, próxima do porto do Rio de Janeiro, a presença de ossos humanos apontou o local como sendo este cemitério. Ali foram enterrados por sessenta anos os escravos que morriam no mercado do Valongo, onde eram vendidos os africanos trazidos pelos navios negreiros ao Rio de Janeiro (Pereira 2007: 74). Embora não tenha sido feita uma escavação sistemática, o material exposto foi recolhido, o local foi examinado e os trabalhos de reforma da residência foram monitorados pela equipe do Instituto de Arqueologia Brasileira, designado pelo Departamento Geral do Patrimônio Cultural do Município do Rio de Janeiro para esta tarefa (Fig. 2). No local, posteriormente, foi criado o Instituto Pretos Novos, organização da comunidade local que há vários anos luta pela preservação do sítio e pela memória africana no Brasil.

Segundo Cavalcante, citado por Pereira (2007: 74) quando este cemitério foi criado pelo Marquês de Lavradio localizava-se no caminho da Gamboa, num trecho que passou a ser chamado de rua do Cemitério (atual rua Pedro Ernesto). Tal como o primeiro cemitério, criado para enterrar os escravos vendidos no porto da Praça XV, o cemitério dos Pretos Novos do Valongo era mantido pela Paróquia de Santa Rita. Pode-se estimar que entre 1769 e 1830 tenha recebido mais de vinte mil corpos de escravos récem-chegados, os "pretos novos”, que morreram antes mesmo de serem vendidos.

$\mathrm{Na}$ falta de um responsável, ou proprietário, que se encarregasse de seu enterro; e na falta de vínculos sociais com irmandades que fizessem esse papel, os enterros, obrigatoriamente cristãos, estavam ao encargo da paróquia de Santa Rita. O aumento do tráfico negreiro, agravando o cenário desolador e insalubre do mercado com seus moribundos e mortos espalhados pelo centro do Rio de 


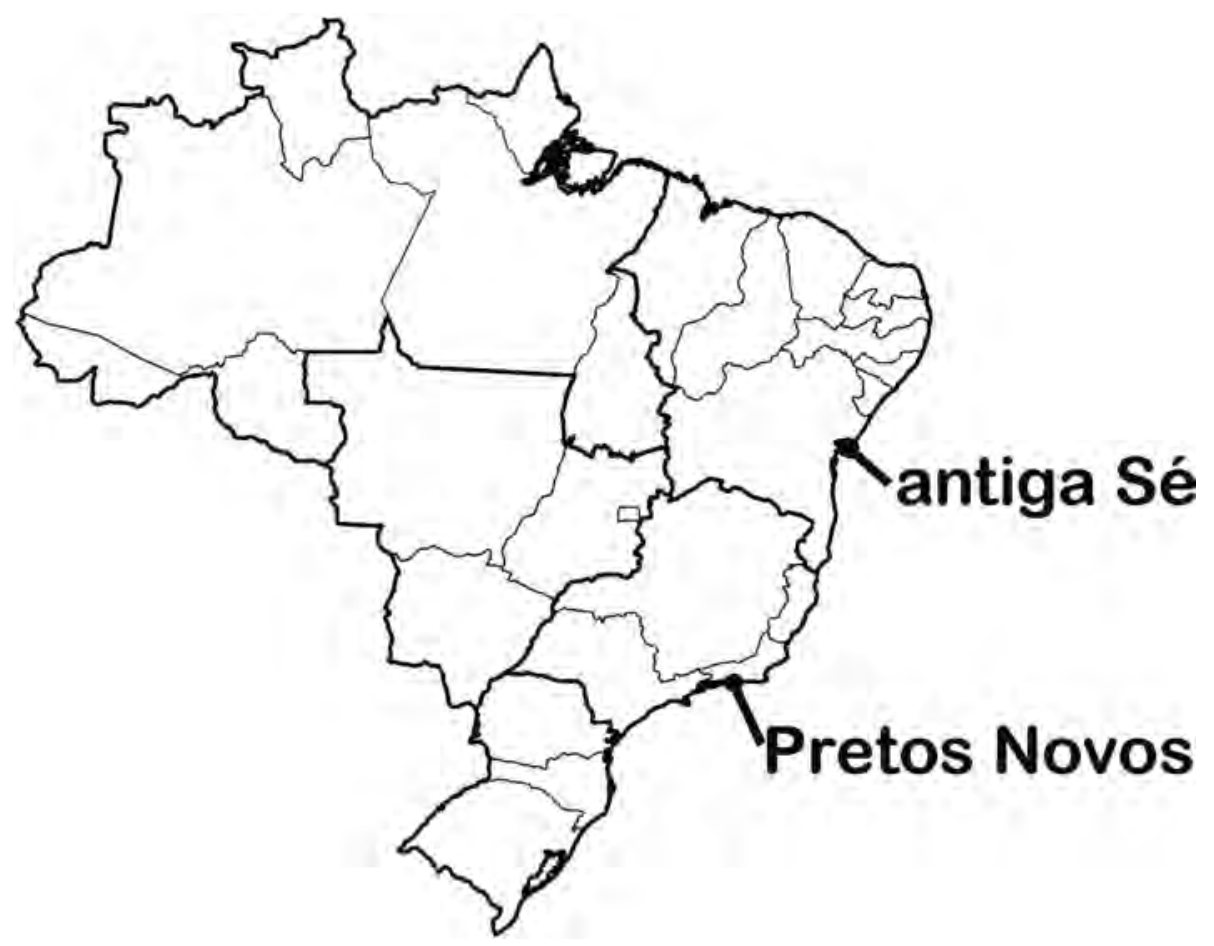

Fig. 1. Localização dos sítios arqueológicos cemitério dos Pretos Novos, no Rio de Janeiro, e da antiga Sé, em Salvador, e respectivas situações na malha urbana.

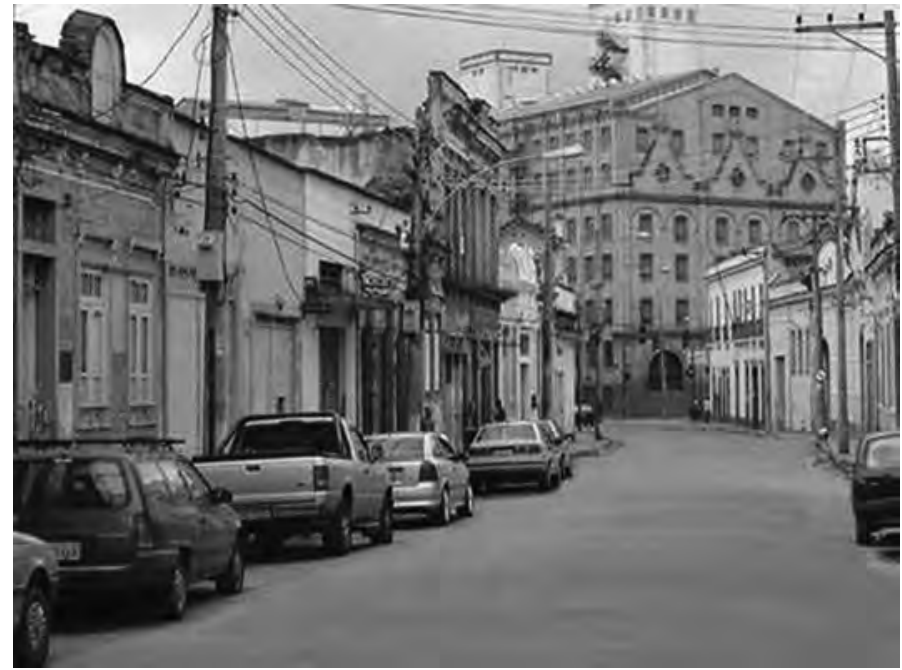

Fig. 2. Vista da Rua Pedro Ernesto, na região portuária do Rio de Janeiro, onde foi localizado o Cemitério dos Pretos Novos.

Janeiro, teria levado ao deslocamento de mercado e cemitério para o Valongo. Segundo Pereira (2007: 100), os registros escritos dos seis últimos anos de uso indicam que tratar-se de um cemitério específico para recém-chegados, o que o torna único na América. Não chegam a $5 \%$ os enterros de africanos já residentes (ladinos), de não-africanos e até de não escravos naquele cemitério.

Os ossos e dentes humanos recuperados no cemitério dos Pretos Novos estavam totalmente dispersos e em situação de re-deposição, sendo provenientes de quatro poços de sondagem feitos para os alicerces de uma nova construção na rua Pedro Ernesto. Mais de 5.500 ossos, dentes e seus fragmentos, com e sem marcas de incineração ou queima, proporcionaram a estimativa de um número mínimo de 30 indivíduos; uma modesta e pouco representativa parcela dos enterros (Machado, 2006). Como o sítio ainda 
não foi escavado, não há dados contextuais detalhados, mas a estratigrafia nos locais de onde saíram os ossos indica duas camadas arqueológicas: o solo arenoso original da praia da Gamboa e sobre ele um aterro areno-argiloso com restos construtivos atestando em parte a urbanização do local. Em ambas as camadas havia ossos humanos e de animais, dentes, fragmentos de louça, vidro, metais e outros materiais culturalmente relevantes como contas africanas e cachimbos. Machado (2006) dedicou-se especialmente a discutir e caracterizar as marcas de incineração e queima nos ossos e dentes, confirmando que grande parte dos corpos havia sido exposta ao fogo antes do enterro, tal como descrito em numerosos documentos. Além disso, aquela autora encarregou-se da primeira descrição bioarqueológica da série.

Os dentes modificados, algumas patologias e as características bioesqueletais descritas foram consistentes com o esperado para uma série representativa dos escravos recém-chegados. O pequeno tamanho do cemitério, e o grande número de enterros, a forma como eram realizados, além das perturbações frequentes no terreno pela urbanização posterior, explicam a re-deposição dos materiais. O achado de dentes humanos intencionalmente modificados e de algumas contas de vidro africanas foram considerados por Machado (2006: 9) testemunhos para confirmar o enterro de africanos no local, atestando a própria identidade do cemitério dos Pretos Novos.

\section{Enterros na Sé de Salvador}

Entre 1998 e 2001 foi feita a escavação das fundações da primeira catedral do Brasil, a antiga Sé situada em Salvador, na Bahia. Tratava-se de uma igreja grande, que começou a ser construída ainda no século XVI, recebendo sepultamentos desde então até 1856 (Boccanera 1921; Carneiro 1980; Peixoto 1980; Etchevarne et al. 1999). Com as reformas e acréscimos ao edifício, houve sucessivas perturbações dos sepultamentos mais antigos. Em 1933, a catedral foi demolida para expansão das linhas de bonde da cidade. Naquele momento foi feita a exumação de parte das sepulturas existentes na nave, e mais perturbações dos enterros remanescentes no adro e entorno da igreja. Sua localização central, na parte nobre da cidade de Salvador, levou a que as reformas urbanas selassem totalmente o terreno original, mascarando a localização da igreja e seu cemitério.

$\mathrm{Na}$ década de 90 foram feitas escavações de salvamento (Etchevarne et al. 1999; 2000; 2001), que deixaram à mostra estruturas arquitetônicas, permitindo recuperar material cultural diverso pertencente aos períodos de ocupação histórica e também evidenciando ocupações pré-históricas interpretadas como Tupiguarani. Objetos de uso doméstico e de uso pessoal, material bélico, restos de cozinha, material construtivo e esqueletos humanos foram recuperados em grande número. Três setores permitiram recuperar ossos e dentes: o setor A, o setor B incluindo parte da nave, da torre sineira direita e pequena parte do adro junto ao alicerce frontal, e o setor F, abrangendo a maior parte do adro (Fig. 3). Poucos ossos humanos foram encontrados no solo da nave, pois a mesma havia sido esvaziada e as sepulturas transladadas quando da demolição da igreja.

Nos setores A e B foram encontrados sepultamentos primários e ossos dispersos. No $\mathrm{B}$, entretanto, havia restos de enterros antigos feitos na frente da torre sineira do século XVI, que estivera anteriormente em posição mais recuada. Estes antigos sepultamentos haviam sido cortados pela construção da nova torre, alinhada à fachada principal, ou passaram a ficar incluídos na área interior da igreja, testemunhando os mais antigos distúrbios nos sepultamentos feitos na Sé. A datação não calibrada de osso humano de um adulto cortado pelo alicerce frontal, forneceu a idade de $480 \pm 60$ (GIF), confirmando que o enterro era anterior ao ano de 1625 , ou da ampliação da igreja (Etchevarne et al. 2000).

No setor $F$ foi encontrada a maior parte dos remanescentes humanos, historicamente descritos como de escravos e indivíduos sem recursos para enterros. A estratigrafia revelou o solo original e também camadas 


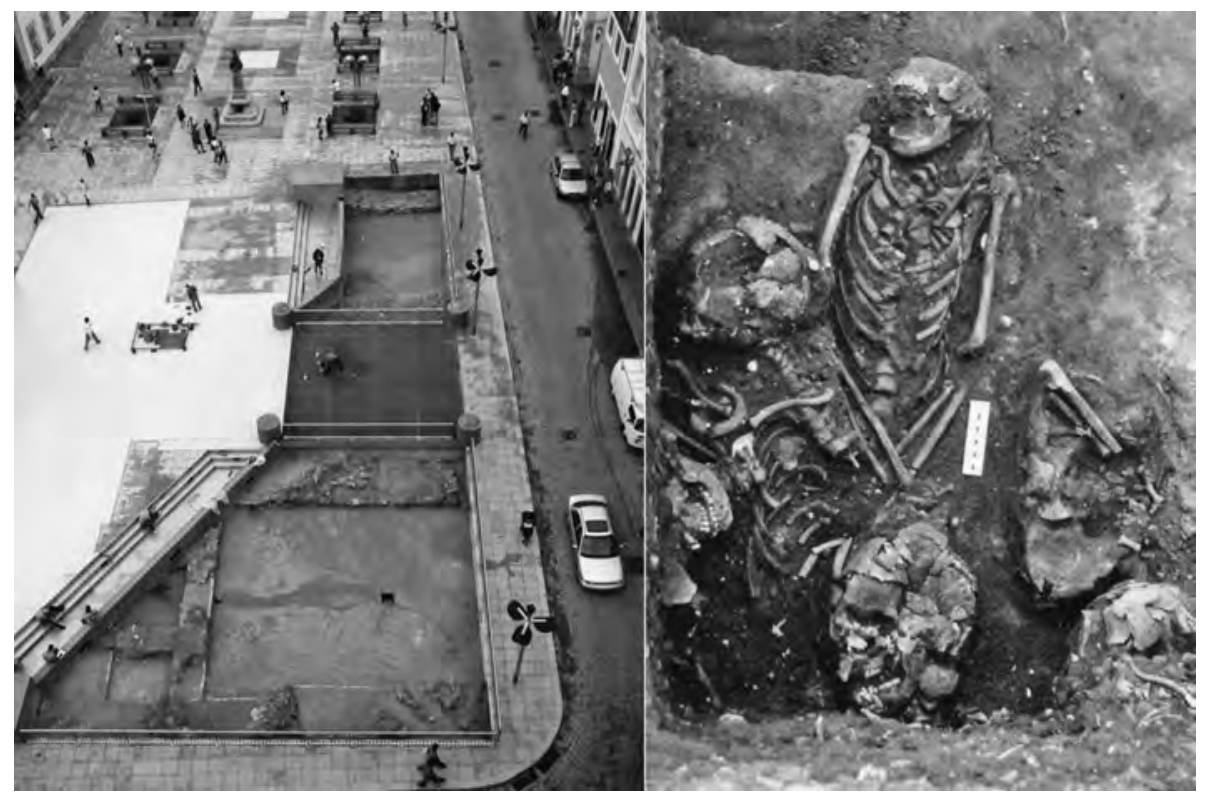

Fig. 3. Vista do centro de Salvador, onde anteriormente erguia-se a Sé, com as áreas de escavações em 1999. E vista dos sepultamentos primários do século XVIII. Fotos: MAE/UFBA.

depositadas de aterros sucessivos, onde havia, respectivamente, enterros primários e deposições secundárias de ossos e dentes provenientes de níveis perturbados. O solo original, ou pacote estratigráfico 2 , forma declive orientado da frente da igreja para o muro de arrimo fronteiriço. Ali, em contexto original do século XVIII, foram encontradas dezenas de sepultamentos primários entre $0,70 \mathrm{~m}$ e $2,00 \mathrm{~m}$ de profundidade. Como relatam Etchevarne et al. (2000: 68-69), a premência da obra pública levou à necessidade de trabalho acelerado, sem que fosse possível a ampla abertura da área escavada. $O$ registro dessa grande quantidade de sepultamentos em diferentes profundidades, afetada por processos sucessivos de aterro e perturbações do terreno, tornou necessário trabalho posterior de curadoria, ainda em andamento. Em alguns destes sepultamentos primários foram encontradas contas típicas da região do Níger, confirmando a forte presença africana no cemitério, tal como discutido por Tavares (2006:3). Apesar de não ter sido totalmente escavada, a área proporcionou abundância de material arqueológico. Liryo (2003) estu- dou a saúde bucal da população representada pela série de arcadas dentárias.

Preenchendo o fosso existente entre o solo original do adro e o muro de arrimo, foi escavado o pacote estratigráfico 4 , formado por diferentes capas de aterro datadas dos séculos XVII, XVIII e XIX, todas contendo ossos e dentes humanos dispersos (Santos 1988; Etchevarne et al. 1999; 2000; 2001). Os dentes aqui descritos foram encontrados principalmente nas camadas intermediárias ou profundas, ou seja, as mais antigas do aterro, já tendo sido objeto de publicação anterior (Liryo, Carvalho \& Souza 2004). Embora não datados, teriam sido re-depositados em diferentes momentos de distúrbio do solo no cemitério, tais como as obras de construção da nova torre sineira, ou a ampliação da igreja no século XVII.

A camada arqueológica superior no setor F representava um aterro do século XIX, feito para nivelamento do terreno quando da construção da Praça Dona Isabel. Esta camada se sobrepõe a toda a área do antigo adro. Embora ali também tenham sido encontrados ossos e dentes esparsos, estes não foram analisados no presente estudo. 


\section{Material e metodologia}

A revisão do acervo do cemitério dos Pretos Novos permitiu analisar 570 dentes, articulados ou avulsos, provenientes de duas camadas arqueológicas cuja espessura atingiu mais de $1 \mathrm{~m}$ de profundidade, mas sem referência estratigráfica, por não terem sido escavados sistematicamente. Todo o material é proveniente da peneiração dos sedimentos retirados dos poços B1, B2, B3 e $\mathrm{B} 4$, abertos no terreno para a reforma da residência que havia no local (Machado 2006: 1).

A maior parte dos ossos humanos estava quebrada, tratando-se de ossadas dispersas. As diferentes concentrações de partes de calota craniana, mandíbulas e ossos longos, bem como o número pequeno de ossos das extremidades (mãos e pés), vértebras e costelas nos diferentes poços, sugerem que os remanescentes humanos já se encontravam re-depositados. Chama atenção a desproporção entre partes de crânio/ maxilares superiores, e as mandíbulas, talvez por seleção e re-deposição, tal como em ossuários criados após exumação para abrir espaço para novos enterros.

Ainda assim, alguns dentes puderam ser rearticulados, ou pelo menos associados a arcadas mais completas. A estimativa de sexo e idade foi dificultada pelas condições do material, mas confirma-se o publicado em Machado (2006: 3), que identificou a maioria dos indivíduos como adolescentes e adultos jovens do sexo masculino, o que era historicamente esperado. Embora não haja datação absoluta para o sítio, assume-se que a cronologia dos ossos corresponda ao período de uso do cemitério, variando entre 1769 a 1830.

A revisão do acervo da Sé não totalizou todos os esqueletos existentes, por ainda se encontrarem em curadoria. Foram constituídas duas séries de estudo, ambas do setor $\mathrm{F}$, mas distintas pelo seu contexto arqueológico. A primeira é proveniente do pacote estratigráfico 4 , formado pelos aterros feitos junto ao muro de arrimo, e que foi considerado como mais antigo. Esta série proporcionou 1289 dentes avulsos correspondentes a um número mínimo, ou NMI, de 64 indivíduos (Liryo 2003: 117). Infelizmente para estes não pode ser feita estimati- va de sexo ou de idade. A segunda é proveniente do pacote estratigráfico 2 , formado pelo solo original do adro contendo enterros primários do século XVIII. Esta série proporcionou 1662 dentes articulados, provenientes de 55 indivíduos, aos quais foram depois somados mais sete analisados por serem portadores de modificação dentária. A estimativa de sexo nos primeiros 55 resultou em 31 femininos e 18 masculinos; e a de idade resultou em 13 jovens, entre 12 e 20 anos, e 42 adultos. Os sete indivíduos adicionais não puderam ainda ser analisados para sexo, idade e condições dentárias.

Os dentes de todas as séries encontravam-se morfologicamente bem preservados, proporcionando coroa completa para exame. Foram eliminados do estudo os exemplares fragmentados.

As análises foram apoiadas na descrição das características morfológicas macroscópicas, e na descrição das características microscópicas das superfícies modificadas dos dentes. A análise quantitativa dos dentes modificados considerou tanto o total de indivíduos, como o total de dentes em cada série estudada, sendo utilizado quando pertinente, o Número Real de Indivíduos - NR -, ou nos casos de material avulso, o Número Mínimo de Indivíduos - NMI. Os dentes foram classificados por tipo e posição anatômica (superior/inferior; direito/esquerdo), e quantificados, antes de terem suas modificações descritas. Sempre que possível os dentes foram re-articulados e associados aos esqueletos existentes (Buikstra \& Ubelaker 1994). O estudo foi precedido de limpeza mecânica suave, com pincéis e escovas macias, e quando necessário o dente foi pincelado com álcool anidro, ou acetona anidra, para remoção de partículas e sedimentos aderidos.

A identificação dos dentes modificados foi feita a partir do contorno geral da coroa dentária, complementado pela observação microscópica do bordo para a confirmação das técnicas de modificação aplicadas à coroa. Foram buscados sinais de cortes, estriamentos paralelos indicativos de limadura ou polimento, sulcos e quebras, indicativas de martelamento e/ou cinzelamento do bordo. Este exame foi feito com auxílio de lupa binocular (40X) e lupa digital PROSCOPE (50X, 30X com polarização). A documentação 
fotográfica foi feita com câmera digital e com a própria lupa digital. As modificações foram classificadas com base em Santos (1962), pela especificidade para séries africanas. Como aquela classificação não abrange todos os tipos encontrados ela foi acrescida de novos tipos/subtipos, baseados nos exemplares observados e também no descrito por Almeida (1953). As formas de modificações foram computadas para cálculo de duas maneiras: a frequência dos tipos de dentes modificados e a frequência dos tipos de modificações observadas em arcadas preservadas.

Exames radiológicos, para visualização dos canais radiculares e câmaras pulpares, só puderam ser empregados até agora nos dentes avulsos da Sé. Foram registrados os sinais patológicos presentes nos tecidos dentários e nos ossos alveolares de acordo com Hillson (1996), tendo em vista a possível correlação de tais lesões com a modificação dos dentes.

\section{Resultados}

Dentes modificados do cemitério dos Pretos Novos, RJ

No cemitério dos Pretos Novos a maior parte dos dentes modificados estava desarticulada (Fig. 4). Apenas dois incisivos centrais com modificação simétrica estavam associados com a maxila correspondente e outros fragmentos do crânio.

Naquele cemitério, o total de 570 dentes examinados correspondeu a um NMI de 30 indivíduos. Do total dos dentes $13(2,3 \%)$ tinham modificações intencionais, sendo as mesmas encontradas apenas nos incisivos, e principalmente nos centrais superiores. Considerando-se apenas os incisivos $13,7 \%$ dos 95 dentes eram modificados. Isto correspondeu a $24 \%$ dos 29 incisivos centrais superiores analisados naquela série. Apenas um incisivo inferior tinha modificação intencional.
O NMI de indivíduos com dentes modificados, estimado a partir destes dentes, foi de cinco indivíduos, o que corresponderia a cerca de 17,9\% dos indivíduos estimados (também com base em dentes recuperados) na série dos Pretos Novos.

Considerando-se a classificação de Santos (1962), apenas um incisivo central superior apresentava a forma correspondente ao tipo a, ou seja, um corte reto para retirada do ângulo mesial. Os demais tinham variações das formas $\mathrm{d}$ e $\mathrm{n}$, sendo caracterizados por cortes em curva, inclinados no sentido mésio-distal, e feitos para remover a totalidade do bordo incisal. De um modo geral a superfície modificada mostra-se bem acabada, cuidadosamente polida e as pontas resultantes da escultura do dente são aguçadas. O bordo resultante está suavizado em todo seu contorno por um acabamento cuidadoso, e ao contrário da Sé, não foram observados contornos retilíneos ou recortes irregulares. No único incisivo central inferior com modificação, ao contrário dos demais, o corte descreve uma convexidade suave, iniciando no terço inferior da coroa e indo até o seu ângulo mesial, o que confere ao dente uma forma peculiar alongada. Seguindo-se a classificação de Santos (1962), foram identificados os tipos a, $\mathrm{d}$, n e duas variantes que chamamos de a"' e n'.

$\mathrm{Na}$ microscopia das superfícies modificadas foi possível ver apenas cicatrizes discretas de retirada do tecido dentário, na forma de sulcos irregulares, ou lascamentos pequenos, orien-

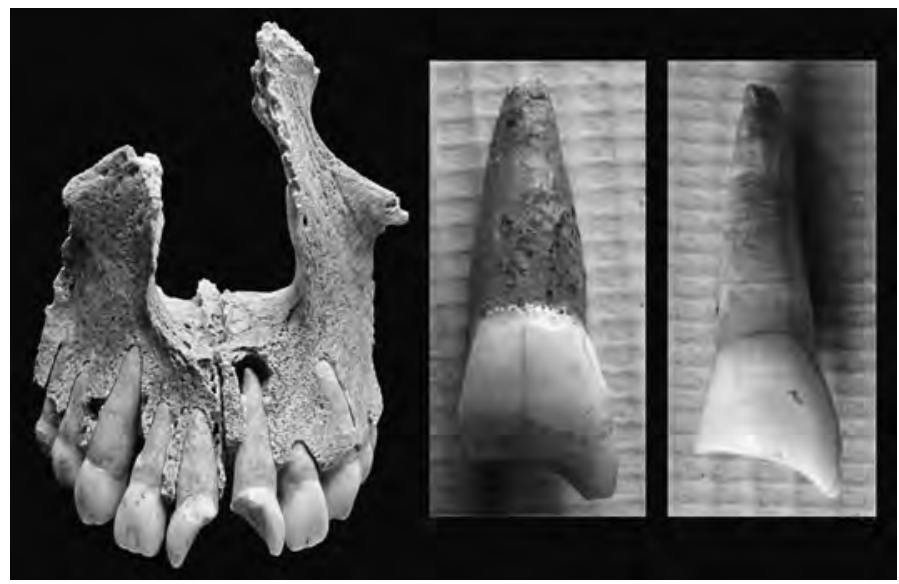

Fig. 4. Dentes modificados encontrados no cemitério dos Pretos Novos, Rio de Janeiro. 
tados obliquamente em relação ao plano do dente. Em algumas áreas há estrias finas que se estendem do bordo modificado até o esmalte contíguo, e que confirmam o polimento subsequente para obter o acabamento desejado.

Num dos incisivos centrais (direito) modificados, no único exemplar com os dentes articulados, observa-se a ocorrência de exposição de polpa causada pelo trabalho de escultura do dente. Uma infecção subsequente, que formou cavidade periapical de drenagem, encontra-se aberta para a face vestibular da maxila, e embora aparente cicatrização, também está circundada por discreta periostite, ou halo inflamatório reacional. Esta foi a única observação de uma complicação diretamente associada à prática de modificação dentária, ainda que não tenha havido perda do dente.

\section{Dentes modificados do cemitério da Sé, BA}

Dos 354 incisivos avulsos provenientes do aterro do adro da Sé, 40 (11,3\%) apresentavam algum tipo de modificação intencional, o que corresponde a 3,1\% do total de dentes avulsos desta série (Fig. 5). Uma única exceção foi o conjunto Se.III.1248, composto por quatro dentes incisivos superiores escavados na mesma quadra e profundidade, juntamente com outros dentes e fragmentos da maxila do mesmo indivíduo. Nesta série, o grande número de dentes com ambos os ângulos cortados dificultou a identificação de lateralidade e, portanto, a estimativa de NMI. A condição do material avulso impediu que se tentasse a correlação de idade e sexo com a modificação dos dentes.

Considerando os 55 sepultamentos primários do século XVIII mais detalhadamente estudados, 18 indivíduos $(32,7 \%)$ tinham modificações nos incisivos. Neste foram examinados 1662 dentes articulados, sendo 46 deles $(2,8 \%)$ modificados intencionalmente. Nas arcadas completas foi possível confirmar o que a etnografia já aponta, as modificações encontradas obedeceram a uma grande simetria. Os incisivos centrais apresentaram maior frequência de modificações que os laterais. Levando-se em conta todos os incisivos articulados da série inicialmente examinada, 46 (11,6\%)

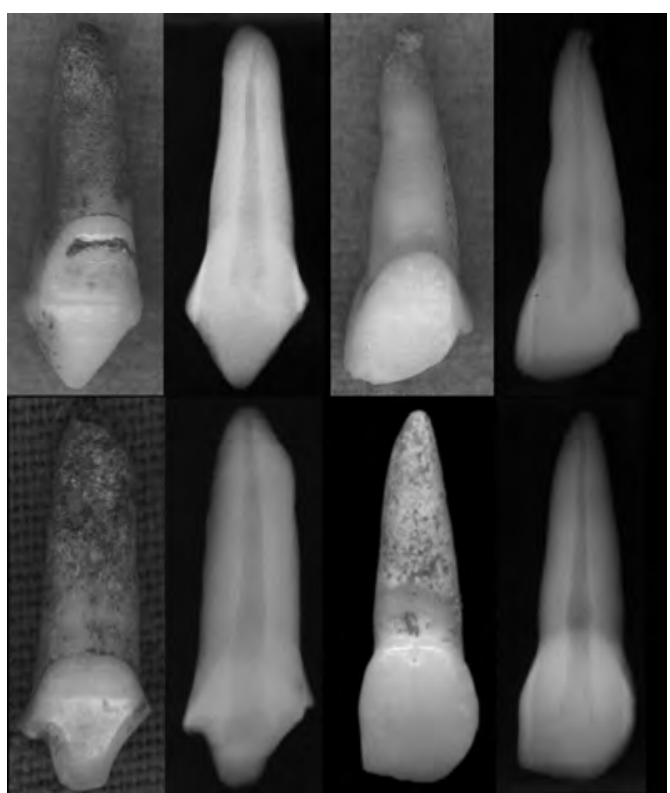

Fig. 5. Alguns exemplos de dentes avulsos modificados encontrados na série do aterro da Sé de Salvador, e respectivas radiografias.

deles apresentavam modificações intencionais. Deve-se levar em conta, no entanto, que se trata de uma série parcialmente selecionada, em que os indivíduos portadores de modificações nos dentes foram prioritariamente separados para curadoria e análise, e assim estes valores devem estar superestimados.

Somadas à série estudada, as sete arcadas de indivíduos com modificações, encontrados posteriormente, ampliaram a amostra, totalizando 25 indivíduos com arcadas modificadas, em 62 indivíduos já examinados da Sé (Fig. 6). Embora tenham sido examinados indivíduos provenientes dos setores $\mathrm{B}$ e $\mathrm{F}$, todos os que tinham dentes modificados encontravam-se sepultados na parte de fora da igreja, e três deles, além das modificações nos dentes, apresentaram também contas africanas de vidro em suas sepulturas, sendo este um reforço à sua identificação étnica.

Reunidos todos os dentes com modificações existentes em ambas as séries da Igreja da Sé, é possivel classificar os tipos a, a', b, c, c', f e o de Santos (1962). Na série de dentes avulsos ocorre a maior parte dos tipos referidos, enquanto na série de dentes articulados ocorrem apenas os tipos a, a', c. Na série avulsa, a frequência de 


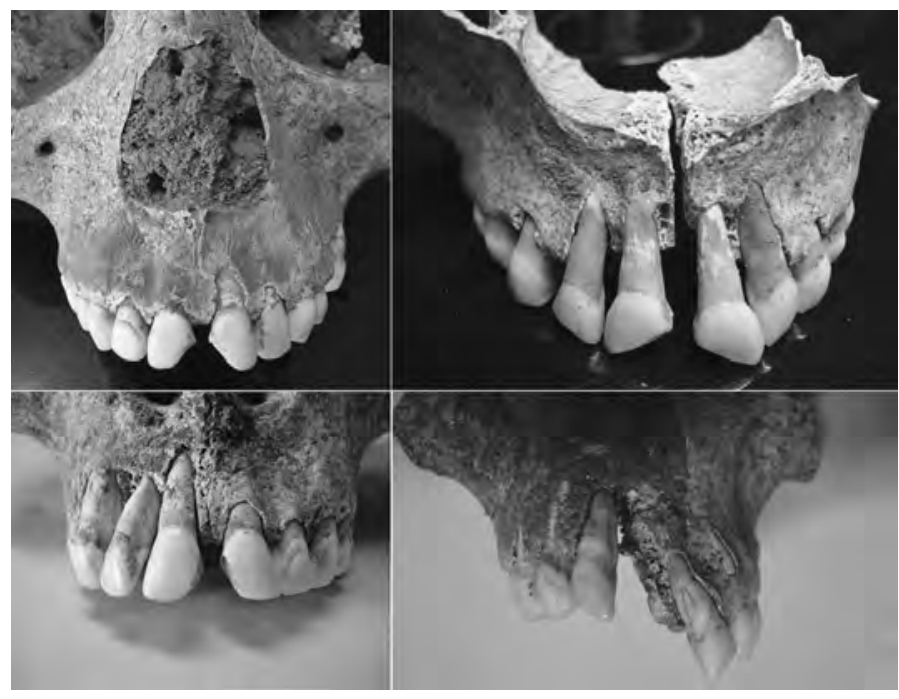

Fig. 6. Arcadas dentárias com modificações intencionais encontradas nos sepultamentos primários do século XVIII da Sé de Salvador. diferentes tipos de modificações é coerente com as diferenças culturais e étnicas nos escravos representados por cada uma das séries de ossos (Tabelas 1 e 2).

Quanto ao tipo de contorno do bordo dentário modificado, na Sé o contorno retilíneo foi o mais frequente, ocorrendo tanto associado à retirada de um, como de ambos os ângulos incisais. Em sete dentes $(17,5 \%)$, os contornos modificados mostram apagamento dos bordos, tanto nos contornos curvilíneos (côncava/convexa/ mista) como nos contornos retilíneos.

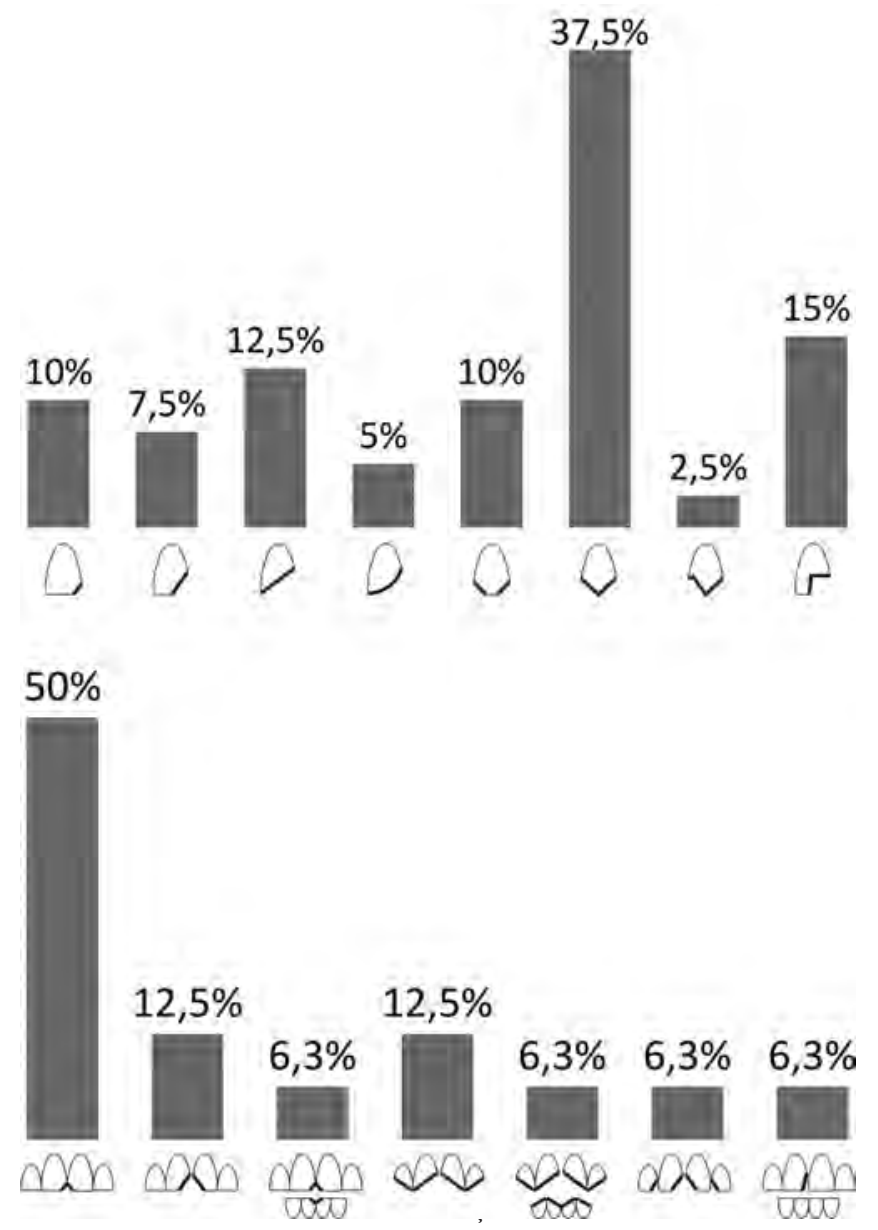

dentes dos tipos c, c' representa quase a metade dos exemplares estudados. Essa diferença percentual entre os tipos encontrados no mesmo sítio da Sé, quando comparados os enterros primários e o material re-depositado, sugeriu que os padrões de modificação dentária seriam diferentes no pacote estratigráfico 2 (primários) e no pacote estratigráfico 4 (re-depositados). A diferença foi estatisticamente significativa quando comparados os dentes com um e com dois ângulos incisais removidos $(p<0,001)$.

Este resultado é coerente com a hipótese de serem os ossos achados em re-deposição provenientes de sepulturas anteriores ao século XVIII, já que historicamente os escravos que chegaram em Salvador antes e depois do século XVIII eram provenientes de diferentes regiões da África. O predomínio de

Fig. 7. Proporções encontradas para os diferentes tipos de dentes modificados e para os diferentes tipos de arcadas dentárias modificadas nos dois sítios estudados 
Tabela 1

\begin{tabular}{ccccc}
\hline \multicolumn{5}{c}{ Modificados da Sé (avulsos) } \\
\hline \hline No & 1 ângulo & 2 ângulos & Retangular & Total \\
\hline Dentes & 16 & 19 & 5 & 40 \\
$\%$ & 40,0 & 47,5 & 12,5 & 100 \\
\hline
\end{tabular}

-se em conta a presença de simetria, pelo menos mais três incisivos superiores (3,1\%), embora ausentes, provavelmente estariam modificados. Um dos exemplares apresentou quebra longitudinal em um dente, o que pode ter sido causado por tentativa frustrada de modificação. Dentre os incisivos inferiores apenas cinco $(2,5 \%)$ mostraram modificação intencional. Levando-se em conta mais uma vez a simetria, mais um $(1,01 \%)$ incisivo central inferior, embora ausente, teria sido modificado.

Considerando-se a quantidade e localização dos dentes modificados, bem como o padrão final obtido nas arcadas dentárias, oito tipos de modificações foram caracterizados nos enterros primários do século XVIII. Na série de dentes avulsos, escavada perto do muro de arrimo, foi encontrado apenas um conjunto articulado com modificações, caracterizando um nono tipo de modificação na Sé.

O tipo de modificação dentária mais popular neste material é representado pela retirada dos dois ângulos centrais dos incisivos centrais superiores, sendo observado em 8 indivíduos $(44,4 \%)$. Este número pode ser aumentado para $10(55,5 \%)$ aplicando-se mais uma vez os critérios de simetria. O segundo tipo em popularidade é formado pela retirada de ângulos proximais dos incisivos centrais e ângulos distais dos incisivos laterais, ocorrendo em três $(16,6 \%)$ dos indivíduos.

Outros quatro diferentes tipos de modificações ocorreram em apenas um indivíduo cada. Foram registrados o corte de ambos os ângulos dos incisivos centrais superiores (\#13, Fig. 8); o corte dos ângulos mesiais dos incisivos centrais superiores e inferiores (\#33, Fig. 8); o corte dos ângulos mesiais dos incisivos centrais e laterais superiores (\#44, Fig. 8) e, finalmente, o corte dos ângulos mesiais dos dentes incisivos centrais superiores e inferiores, e dos ângulos distais dos
Tabela 2

\begin{tabular}{|c|c|c|c|c|}
\hline \multicolumn{5}{|c|}{ Modificados da Sé (articulados) } \\
\hline No & 1 ângulo & 2 ângulos & Retangular & Total \\
\hline Dentes & 45 & 1 & 0 & 46 \\
\hline$\%$ & 97,8 & 2,2 & 0,0 & 100 \\
\hline
\end{tabular}

incisivos laterais superiores e inferiores ( $\# 42$, Fig. 8), criando um serrilhado formado pelos incisivos laterais e centrais em sequência, e configurando o mais elaborado tipo de modificação registrado neste trabalho.

No exemplar Se.26 das arcadas dentárias da Sé, os bordos modificados apresentam arestas agudas e irregulares, e as formas dos contornos modificados são pouco definidas. A falta de polimento intencional ou decorrente do uso dos dentes e os contornos observados sugerem que o indivíduo teria morrido pouco tempo após a confecção daquela etapa da modificação dos dentes, sem que tenha havido tempo para seu acabamento final ou seu desgaste pela mastigação.

Na maior parte dos casos, no entanto, assim como nos dentes avulsos, o exame microscópico dos dentes articulados mostrou cicatrizes da técnica empregada na modificação. As cicatrizes, embora semelhantes às observadas nos dentes avulsos, estavam mais apagadas pelo polimento/ acabamento posterior, e em alguns casos possivelmente pelo uso.

\section{Discussão}

O estudo de dentes humanos modificados encontrados nos cemitérios da Sé de Salvador, BA, e dos Pretos Novos, RJ, ajudou a aprofundar o conhecimento sobre os padrões de modificações dentárias intencionais de origem africana existentes no Brasil. Em ambos os cemitérios está historicamente documentada a presença de não-africanos, cujos sepultamentos foram registrados pelas irmandades ou igrejas encarregadas dos funerais (Reis 1991; Pereira 2007). Já está confirmado que, ao contrário dos Estados Unidos da América do Norte, o Brasil testemunhou a persistência destas práticas 
até meados do século XX (Netto 1882; Amaral 1968). Por esta razão, ao menos parte dos achados de dentes modificados encontrados em cemitérios históricos brasileiros podem provir de enterros de crioulos, ou de outros brasileiros, que tenham adotado esta prática cultural. Uma vez que os focos desta transmissão cultural ainda são nebulosos, sendo poucos os estudos específicos sobre o tema, essa interpretação deve ser cuidadosa, principalmente em Salvador, já que a Bahia parece ter tido um dos mais expressivos eixos de popularização das modificações dentárias entre não escravos.

Por outro lado, a literatura mostra que a continuidade das modificações dentárias intencionais no Brasil parece ter selecionado um padrão: o corte de ambos os ângulos incisais em dois, ou quatro dos incisivos superiores. Essa forma de dente, com maior ou menor arredondamento dos bordos, deixando ou não pequeno segmento incisal entre as áreas removidas (tipos b, c, c'), é vista em todos os exemplos de modificação dentária em brasileiros, ou em indígenas, que a adotaram no Brasil. No sertão esta prática era denominada de "afastagem”, "limagem”, “despontagem” ou "talhagem”, tendo sido reportada até a primeira metade do século XX. Durante exames odontológicos de rotina, Amaral (1968) identificou dezenas de marinheiros brasileiros portadores daqueles tipos de modificações dentárias intencionais. Em suas anamneses, identificou a origem daqueles indivíduos, provenientes do sertão de Pernambuco, Rio Grande do Norte, Maranhão e Sergipe, o que corresponde à área de influência do Rio São Francisco, aparentemente um dos eixos de dispersão desta prática, tal como indicado originalmente por Netto (1882). Outro eixo seria ao longo do rio das Contas, na Bahia, mas próximo a Salvador. Em ambos os casos deve ser levado em conta que os achados da Sé poderiam expressar essa prática de modificação por não africanos, talvez as primeiras expressões dessa aculturação.

Entre os enterros primários do século XVIII, existe uma proporção historicamente documentada de $70 \%$ de africanos, o que é reforçado pelo achado de acompanhamentos funerários como as contas de vidro Yorubá. Ali, os tipos de modificação encontrados também falam em favor de africanos, e não de brasileiros. Apenas um indivíduo dentre os 25 até agora encontrados com dentes modificados (4\%) apresentou o tipo "dentes de piranha”. Assim sendo, admitimos que os enterros primários da Sé testemunhariam realmente a presença de africanos de origem.

No aterro junto ao muro de arrimo, por outro lado, cerca de metade dos dentes modificados tinham os dois ângulos cortados. Esta diferença foi estatisticamente significativa quando comparada com os achados semelhantes nos sepultamentos primários. Ainda que não haja datação absoluta para estes dentes, a sua proveniência de camadas médias e profundas do aterro, os torna anteriores ao século XVIII. Estes dentes apresentam cicatrizes de cinzelamento, sugerindo que tenham sido esculpidos da forma tradicional, levando à interpretação, ou seja com uso de técnicas africanas. $\mathrm{O}$ achado, em deposição secundária, representaria escravos sepultados em períodos anteriores ao dos enterros primários. Tais re-deposições poderiam representar o material exumado dos enterros mais antigos, perturbados por obras como a construção da torre alinhada ao frontão da igreja, por exemplo.

No cemitério dos Pretos Novos, por outro lado, os dentes modificados apresentam forma e acabamento esmerados, diferentes dos tipos encontrados, mais tarde, entre brasileiros. Como não há referência à prática de modificações nos dentes entre brasileiros no Rio de Janeiro, sua origem africana se reforça, principalmente pela preponderância de enterros de africanos naquele cemitério da Gamboa (95\%).

A tentativa de associar tipos de modificação dentária com etnias específicas foi mal sucedida, mesmo a partir de arcadas dentárias completas. O número de tipos de modificações feitas pelos grupos africanos é pequeno, e os mesmos tipos são usados por diferentes etnias/áreas culturais. Uma intensa dinâmica social e cultural faz com que a mesma prática possa ser adotada por indivíduos de diferentes grupos, havendo inclusive relatos da liberdade de escolha individual levando a variações nas modificações executadas (Almeida 1953: 3636). 
As formas dos dentes associadas às suas posições nas arcadas configuraram os tipos de arcadas modificadas. Classificações e descrições etnográficas na literatura apontam para algumas associações, que aqui foram consideradas como ponto de partida para sua classificação.

Com base em Santos (1962), foi possível identificar alguns tipos de modificações feitas nos dentes. Mas como seu trabalho restringe-se a Moçambique, outros autores que proporcionam dados para a costa Atlântica (Angola, Nigéria, Congo) também foram consultados. No conjunto de dentes articulados da Sé as modificações foram coerentes com o registrado para o período em que predomina a vinda de escravos sudaneses para Salvador. Dados obtidos na Cúria Metropolitana de Salvador (Tavares 2006) informam apenas vagamente a origem dos indivíduos sepultados na Sé, o que é ratificado por outros autores. Entre os séculos XVII e XIX $70 \%$ dos enterros seriam de africanos, destes mais da metade sudaneses, em detrimento dos que vinham de portos Bantu, da região congo-angolana (Verger 1987: 7). No entanto, a variedade de modificações encontrada na Sé suscita a discussão da diversidade étnica vinda para o Brasil. $\mathrm{O}$ achado incluiu dentes arqueológicos semelhantes às formas $f, f^{\prime}$ de Santos (1962: 272). Achado semelhante foi também descrito por Singer entre africanos sepultados no Cabo, África do Sul, cuja origem foi confirmada em associação ao naufrágio de um navio negreiro que contornava o extremo sul da África vindo de Oriente (Singer 1953: 121).

Embora algumas modificações dentárias observadas sejam encontradas tanto a Oeste como ao Leste da África (Vianna Filho 1946; Amaral 1968; Pereira Filho 1968; Jones 1992), foram encontrados valores diferentes estatisticamente significativos para dentes com um e dois ângulos retirados, quando comparados os valores das duas séries da Sé. Como enfatiza Vianna Filho (1946: 76) ... À concentração de elementos Bântus no século anterior substituiria a predominância dos negros sudaneses, que dariam à cidade um novo aspecto. Era outra gente. Jorubas, mais conhecidos pelo apelido de Nagôs, Tapas, Bambarras, Haussás, Achantis, Gêges, Bornus, Fulahs e Mandingas, encheriam a antiga capital brasileira, impondo-se como grupo negro mais numeroso. Na Sé acrescenta-se que 16 dos enterros primários da camada 2 estavam acompanhados de contas de vidro Yorubá, havendo em dois deles modificações dentárias intencionais. Esse achado reforçou a associação funerária com africanos da Costa da Mina, reconfirmando os dados históricos (Tavares 2006: 15-16). Na camada 4, ou aterro, por outro lado, a maior frequência de modificações do tipo "dente de piranha" remete às etnias da África Centro Ocidental. A cronologia dos dentes avulsos como pertencentes ao século XVII permite uma associação consistente com os dados históricos, já que nessa época a escravaria seria originada da costa Centro-Ocidental da África, ou congo-angolana, onde tipos como “dentes de piranha” são modificações muito populares.

A distribuição espacial dos enterros primários de indivíduos portadores de modificações dentárias no espaço funerário do adro da Sé, por sua vez, chama atenção para um aspecto socialmente relevante. Alguns indivíduos portadores de modificações dentárias semelhantes foram sepultados muito próximos (Fig. 8). O uso daquele cemitério por africanos da cidade de Salvador certamente seria opcional, a partir da sua filiação à irmandade. A colocação em espaços próximos de indivíduos com padrões dentários modificados de maneira semelhante aponta para afinidades étnicas, sociais e familiares, aspectos a serem mais bem estudados futuramente.

No cemitério dos Pretos Novos, do mercado de escravos, por outro lado, havia predomínio comprovado de africanos. Muito embora a importação de escravos para o Rio de Janeiro tivesse tido mais de $70 \%$ de indivíduos da costa Central do Atlântico (principalmente de origem congo-angolana) contra menores proporções de indivíduos provenientes do Índico, ou África Oriental, as proporções se invertem progressivamente ao final do tráfico (Florentino 2002: 80-82). Além disso, havia grande diferença nos riscos de morte para os indivíduos vindos destas duas regiões, principalmente por ser o translado da África Oriental muito mais longo. Desta forma, no cemitério, as proporções dos mortos 

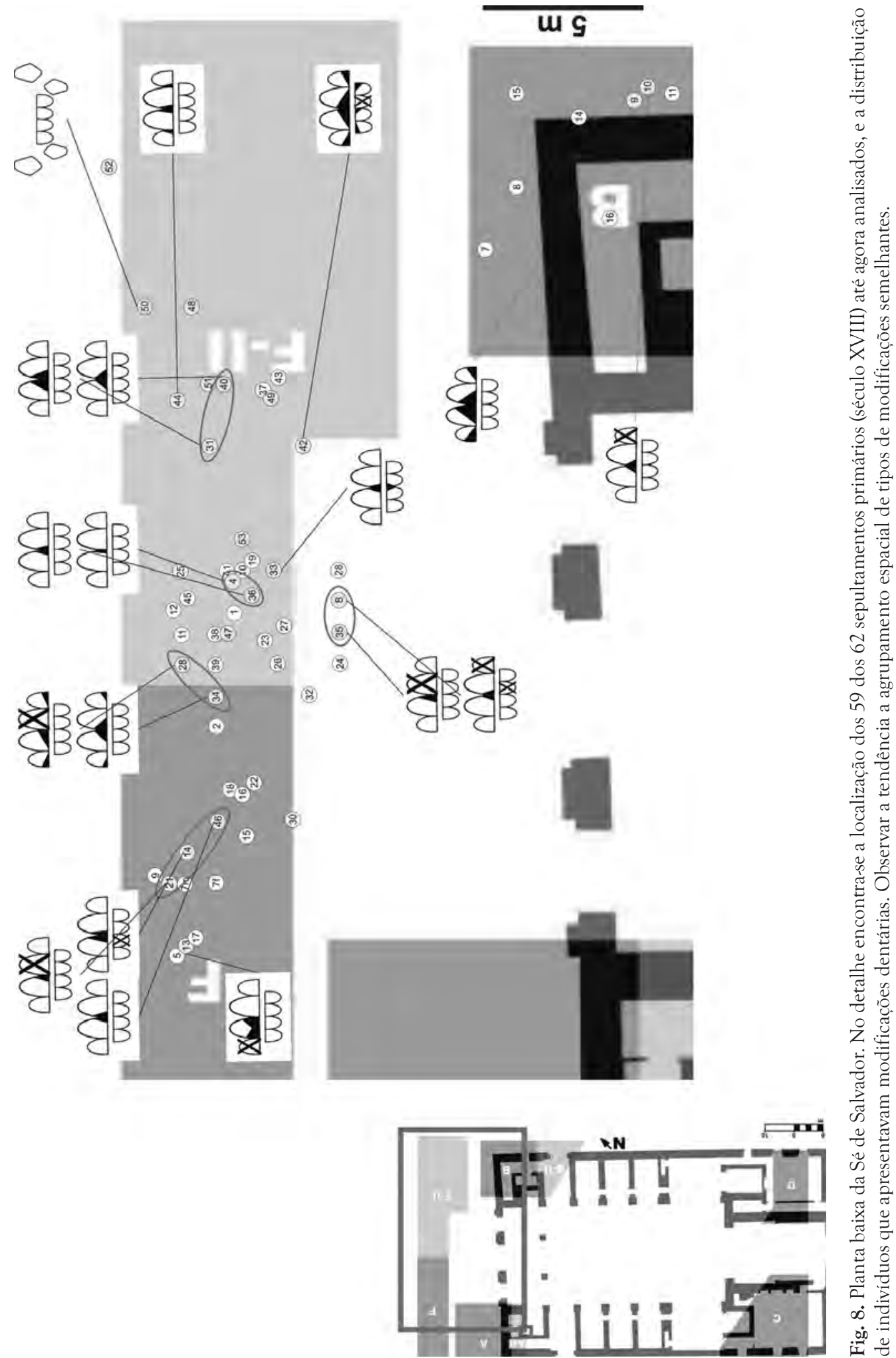
de ambas as regiões podem ter chegado a ser até equivalentes em alguns períodos. Talvez por isto, o tipo de modificação encontrada na maior parte dos dentes do Rio de Janeiro aproximou-se dos tipos e do estilo descritos por Santos (1962) para Moçambique. Cabe lembrar, entretanto, que há sobreposição étnica de estilos e tipos de modificação na literatura (Almeida 1953: 3636). Nos achados do cemitério de náufragos vindos do Índico, Singer (1953: 121) também refere modificações semelhantes às mais observadas nos dentes dos Pretos Novos.

O único exemplar com dentes articulados que pode ser estudado na série do Rio de Janeiro apresenta um padrão de modificação que não se encontra representado em Santos (1962), mas que é referido por outros autores, como Almeida (1953: 3609). O recorte simétrico, curvilíneo removendo o ângulo mesial e a maior parte do rebordo dos incisivos centrais está descrito para grupos do Congo, remetendo por sua vez aos portos da Costa Atlântica. Um achado semelhante foi descrito para dentes modificados encontrados em sepultamentos de escravos exumados junto à igreja de Suruí, no Rio de Janeiro, e relacionados às propriedades rurais do ciclo de café do século XIX (Cunha 1973).

As cicatrizes deixadas pela modificação intencional dos dentes de ambos os sítios são consistentes com as descrições feitas por Dembo \& Imbelloni (1938: 160-165) e outros, para a África. A escultura do dente seria feita com auxílio de pequenos cinzeis de ferro, ou facas e outros objetos (Almeida, 1953: 3608-3609), com os quais seriam progressivamente quebrados os bordos dos dentes, para obtenção do contorno desejado. A depender da forma e do acabamento final, este processo poderia cobrir mais de uma etapa de confecção, demandando trabalho esmerado e de especialista. Ao contrário de outras técnicas que retiram o tecido dentário de um só golpe, ou em um só tempo (Cunha 1968a: 20; Lima 1954: 10), as técnicas percebidas aqui eram de retirada progressiva e acabamento adicional, proporcionando inclusive a elaboração de formas caprichosas de modificação. Há sobreposição de estrias, indicando um lixamento, limadura ou polimento posterior. Ambos os aspectos foram considerados como indicativos de que a modificação dos dentes foi feita da maneira tradicional.

O translado dos africanos para o Brasil, sua diluição social, a eventual falta de representantes da étnica com atribuição social de modificar os dentes, a falta de condições sociais para manter este procedimento estético ou ritual, além da condição servil e expropriação do seu corpo, seriam suficientes para explicar a dificuldade em manter esta, como outras práticas culturais. Por outro lado a existência de uma memória cultural poderia explicar o retorno das modificações dentárias, ainda que com técnicas simplificadas, em comunidades tanto indígenas quanto brasileiras livres ainda no século XIX, e sua continuidade até o século XX em diferentes regiões do país. Os materiais aqui estudados, devidamente contextualizados, confirmam a presença de modificações intencionais dos dentes cujos tipos e técnicas seriam identificadoras de indivíduos nascidos em África, ainda que alguns tipos de modificações semelhantes tenham sido praticadas também no Brasil. $\mathrm{O}$ achado de técnicas tradicionais de escultura dos dentes nas séries aqui estudadas seriam, portanto, critérios diferenciadores para achados arqueológicos em nosso país, ainda que sua aplicação esteja prejudicada em alguns indivíduos com dentes mais fortemente impactados pelo uso posterior à modificação.

O exame microscópico mostrou que a presença de formas arredondadas e aguçadas dos dentes, recortados em curvas suaves, correspondia à presença mais evidente de estrias microscópicas de polimento na superfície modificada. Este aspecto foi mais notável no cemitério dos Pretos Novos, onde um exemplar com dois incisivos centrais esculpidos formam uma grande abertura central em forma de alicate, $\mathrm{o}$ que devia dar em vida um aspecto inusitado e assustador ao indivíduo. As práticas da limagem e do polimento, complementares ao cinzelamento estão descritas por Delfino (1948: 97-98;107108), entre outros.

As faces resultantes das modificações dentárias são explicadas de diferentes maneiras na etnografia, e estão representadas em pinturas, máscaras, esculturas e outros materiais, hoje presentes em diferentes coleções de arte, como 
no Museu de Minneapolis, onde um conjunto notável de materiais africanos oferece belos exemplos deste registro. Curiosamente, apesar da representação e das descrições etnográficas, foi observada baixa frequência de indivíduos com modificações nos dentes em todas as séries estudadas. Isto é confirmado por dados históricos referentes aos Estados Unidos (Handler et al. 1982: 305). Em estudos como do cemitério de Cedar Grove (Wilson \& Cabak 2004) tais modificações parecem mesmo ter estado ausentes entre os africanos. No Brasil, dados históricos obtidos a partir do estudo dos anúncios de jornais, referentes a escravos fugidos, estimam que 5\% tinham modificações nos dentes, tal como propõe Amantino a partir de um universo de 106 indivíduos: " 14 eram africanos que possuíam traços distintivos de sua cultura de origem marcados definitivamente nos corpos: 7 tinham nos rostos, peito e braços, as marcas de suas nações; 5 possuíam os dentes limados ou abertos, 1 possuía um furo no lábio superior e 1 tinha as orelhas com furos" (Amantino 2001: 136).

Na literatura etnográfica a proporção de africanos portadores de modificações dos dentes é muito variável, dependendo do grupo étnico. Segundo Almeida (1953), as frequências chegam a cerca de $90 \%$ em homens e mulheres de grupos como Quiôco e Lunda, de Angola, enquanto em outros, como os Benalulua, também de Angola, ficam em torno de 40\% dos indivíduos (Almeida 1953: 3627-2630). Já Santos (1962:

17) descreve variadas percentagens de modificações em 25 grupos de Moçambique, entre eles Atéues, Djongas, Macuas e Tongas. A literatura refere ainda que a idade em que esta prática ocorreria seria em geral após a puberdade, e em alguns casos apenas no adulto. A presença de uma proporção aparentemente baixa de indivíduos com os dentes modificados nas séries americanas, portanto, deve ser mais discutida.

Admitindo-se que estes números sejam reais, deve-se considerar que na maior parte dos cemitérios estudados na América, e isso se aplica à Sé, a proporção de africanos é variável, e em geral não muito precisamente definida. Uma vez que a prática de modificação dos dentes não teria sido perpetuada na maior parte da América, a frequência esperada de tais achados, principalmente em cemitérios mistos seria mais baixa do que aquela de África. Por outro lado, a baixa frequência em anúncios de fugitivos poderia ser um viés, já que estes documentos são pouco numerosos. Da mesma forma pode-se interpretar os achados no cemitério dos Pretos Novos, cujo número de indivíduos estudados é muito pequeno. Ainda assim, se as proporções baixas de modificações dentárias nos cemitérios de escravos no Brasil forem representativas da realidade, deve ser levado em conta que parte substancial dos indivíduos podem ter sido trazidos antes da idade em que a modificação seria feita, ou que os modificados podem ter sido preteridos enquanto mercadoria.

Outro aspecto sempre recorrente nas discussões sobre as modificações dos dentes é que esta seria um fator de risco para o decaimento dos dentes e da saúde em geral. Embora este tema não tenha sido explorado sistematicamente no presente trabalho, a frequência de cáries entre os dentes avulsos foi de 7,8\% em dentes modificados, e de $9,9 \%$ em dentes não modificados da Sé. É interessante lembrar que a retirada dos ângulos dos dentes é creditada por outros como um procedimento preventivo das cáries inter-dentais, por reduzir a área de contatos entre os dentes, e consequentemente a retenção de alimentos. Ainda nos dentes avulsos o exame radiológico feito para o presente trabalho não revelou patologias expressivas. Muito embora tenha sido encontrado um abcesso periapical associado a um dos dentes modificados da série dos Pretos Novos, nos 18 exemplares articulados da Sé apenas $1.5 \%$ dos loci apresentava cavidade apical, e apenas $1 \%$ deles apresentou perda em vida, confirmando baixa frequência de eventos infecciosos, mesmo em indivíduos com dentes modificados.

Tal como visto, as modificações geralmente se caracterizam pela escultura de pontas, criando padrões de oclusão e mordida muito modificados. Em alguns dentes foram observados desgastes posteriores à modificação, como já chamaram atenção Liryo, Carvalho e Souza (2001: 134), provavelmente associados aos novos contatos oclusais decorrentes. Na série da Sé, um conjunto maior de indivíduos com arcadas completas confirma esta hipótese, sendo possí- 
vel observar a formação de facetas especiais de desgaste também na arcada inferior.

Confirmando ainda o que está descrito na literatura, houve predomínio absoluto de modificações nos dentes incisivos centrais e superiores. A proporção é de cerca de 10 vezes mais modificações nas maxilas que nas mandíbulas, em ambos os sítios, embora o número de exemplares na série dos Pretos Novos sendo muito inferior possa ser pouco representativo.

Em relação à avulsão dentária, apenas um caso sugestivo (\#50, Fig. 8) foi registrado entre as arcadas adicionadas posteriormente ao estudo dos esqueletos articulados da Sé. A prática de avulsão está descrita para todas as regiões de onde vieram escravos para o Brasil, embora Singer (1953: 116) a associe principalmente aos povos do Índico, ou da Costa Oriental da África. Um exemplo deste tipo também foi encontrado nos escravos exumados em Suruí, Rio de Janeiro (Cunha 1973: 16).

\section{Considerações finais}

Devido ao fato de diversas populações africanas terem praticado as modificações dentárias intencionais, os sítios arqueológicos com sepultamentos de escravos têm grande chance de apresentar exemplares com esta marca cultural. Porém, as modificações não podem ser unicamente associadas à origem africana. Aqui no Brasil, tal como em Cuba, não-africanos assimilaram esta prática que passou a ser feita, ainda que por diferentes técnicas, até o século XX. No caso do Brasil, a modificação dos dentes foi praticada por caboclos e indígenas, mas paradoxalmente não é descrito entre os próprios descendentes africanos diretos, como os quilombolas.

Nos dois sítios cemitérios aqui estudados a presença de escravos africanos, mas também de crioulos e mestiços, levou a questionar se o achado de tais modificações dentárias representaria ou não a confirmação da origem africana para os indivíduos. Nas duas séries da Sé de Salvador, os achados mostram compatibilidade entre modalidades de modificação, técnicas de execução e diferenças históricas do tráfico de escravos para a região em momentos diferentes da história. No cemitério dos Pretos Novos, tal como já sugerido anteriormente, as modalidades de modificação também são consistentes com os dados históricos sobre o cemitério. A origem e a cronologia dos enterros de escravos Fluminenses e Baianos podem explicar em parte as diferenças entre as séries de Salvador e do Rio de Janeiro, mas certamente a primeira, contando com um maior número de exemplares, é mais representativa, traduzindo de maneira inédita a grande diversidade de modalidades de modificações dentárias intencionais trazidas ao Brasil durante o período. Em Salvador, além disso, luzes adicionais sobre a distribuição espacial dos enterros e as redes sociais e étnicas por trás dos funerais, podem ser sugeridas a partir de uma análise espacial simples e inicial. Contextualizar as séries ajudou muito mais a entender a inserção das modificações culturais, do que o caminho inverso de caracterizar os sítios pela simples presença dos dentes modificados.

Como este estudo não incluiu todos os indivíduos escavados na antiga Sé, existe a possibilidade de futuramente estender o trabalho e incluir os outros esqueletos ainda não examinados, o que poderá trazer novos elementos para o conhecimento sobre a prática de modificações dentárias no Brasil.

\section{Agradecimentos}

Este trabalho recebeu apoio financeiro da Faperj concedido a Ricardo Ventura Santos (auxílio E-26/102.935/2008) para desenvolvimento do projeto Por uma antropologia biológica do tráfico de escravos africanos para o Brasil. Agradecemos também a valiosa colaboração de Teresa Mendonça, Doutoranda da Universidade de Coimbra e aos Drs. Carlos Etchevarne e Carlos Caruso, por facultarem acesso ao Museu de Arqueologia e Etnologia da UFBA e pelo acesso à coleção e relatórios da Sé. Agradecemos finalmente aos Drs. Ondemar Ferreira Dias Júnior e Glaucia Malerba Sene, e à arqueóloga Laura da Piedade Silva, pelo acesso ao acervo do cemitério dos Pretos Novos, sob guarda do Instituto de Arqueologia Brasileira, e pelo acesso à documentação necessária para nosso trabalho. 
LIRYO, A.; SOUZA, S.M.; COOK, D.C. Intentionally modified teeth and ethnicity in cemeteries of Brazil from colonial and Empire periods. R. Museu Arq. Etn., São Paulo, n. 21, p. 315-334, 2011.

Abstract: Intentional modification of the teeth was very common in Africa, coming to America with the slaves. In two historical cemeteries of Brazil, named Pretos Novos, in Rio de Janeiro (the only burial ground from a slave market ever known in America) and the burial ground of the old Sé, the more important church of Salvador.13 modified teeth were identified among 570 teeth (30 individuals) from Pretos Novos. 122 modified teeth were identified among 3181 teeth from Sé $\left(62\right.$ individuals, primary burials, $18^{\text {th }}$ century and non estimated number of comingled skeletons from other periods). The result of the analysis revealed 13 different modification styles, and 10 different compositions of modified dental arches. The differences are suggestive of different geographical origins for the slaves in both cemeteries, and this result is consistent with historical data. In the Sé burial ground, the proximity of burials of individuals with similar dental modifications is suggestive of ethnic, or social, may be familial links of the dead.

Keywords: Intentional dental modification - Slavery - Historical archaeology Bioarchaeology - Brazil - Africa.

\section{Referências bibliográficas}

ALMEIDA, R.

1953 Mutilações Dentárias nos Negros da Lunda. Anais do Instituto de Medicina Tropical. Lisboa, X (4), Fascículo 2: 3601-3639.

AMANTINO, M.S.

1996 O Mundo dos Fugitivos. Rio de Janeiro na Segunda Metade do Século XIX Dissertação de Mestrado. Rio de Janeiro, IFCS/UFRJ.

2001 O Mundo das Feras: os moradores do sertão oeste de Minas Gerais, século XVIII. Tese de Doutorado. Rio de Janeiro, IFCS/ UFRJ

AMARAL, J.M.

1968 Aspecto Histórico da Mutilação Dentária e sua Influência em Nossos Marinheiros de Guerra. In: Anais da Academia Brasileira de Odontologia (Raridades Bibliográficas de Patronos da Academia). São Paulo: 181-96.

BLAKEY, M.L.

2001 Bioarchaeology of the African Diaspora in the Americas: Its Origins and Scope. Annual Review of Anthropology, 30: 387-422.
BOCCANERA JR, S.

1921 Bahia Histórica. Salvador: Ed. Instituto Geográfico e Histórico da Bahia.

BUIKSTRA J.; UBELAKER, D.

1994 Standards for Data Collection from Human Skeletal Remains. Fayetteville, Arkansas: Arkansas Archaeological Survey Research Series No. 44.

CARNEIRO, E.

1980 A Cidade do Salvador (1549): uma reconstituição histórica. 2a ed. Rio de Janeiro: Civilização Brasileira/Brasília: INL.

CUNHA, E. DE M.S.

1968a Mutilações Dentária no Negro, no Brasil. In: Anais da Sexta Jornada Fluminense de Odontologia "Prof. Coelho e Souza". Niterói, out.: 19-26.

1968b Considerações sobre Mutilações Dentárias no Brasil. Arquivos Fluminenses de Odontologia. Niterói, 1 (3): 18-24.

1973 O Dente do Escravo da Baixada Fluminense: alguns aspectos (Nota prévia). Arquivos Fluminenses de Odontologia. Niterói, 4 (1): $14-19$. 
DELFINO, A.

1948 Alteraciones Dento-maxilares Intencionales de Carácter Étnico: nueva classificación. Revista del Museo de La Plata (Nueva Serie). La Plata, 4 (19): 93-115.

DEMBO, A.; IMBELLONI, J.

1938 Deformaciones Intencionales del Cuerpo Humano de Carácter Étnico. Buenos Aires: Jose Anesi.

ETCHEVARNE, C.; PALERMO, F.; SOUSA, A.C.

1999 Sítio antiga igreja da Sé - relatório da primeira etapa do plano de intervenção arqueológica. Salvador: MAE/UFBA (mecanografado).

2000 Sítio antiga igreja da Sé - relatório da segunda etapa do plano de intervenção arqueológica. Salvador: MAE/UFBA (mecanografado).

2001 Sítio antiga igreja da Sé - relatório da segunda etapa do plano de intervenção arqueológica. Salvador: MAE/UFBA, (mecanografado).

FABIAN, F.M.; MUMGHAMBA, E.G.S.

2007 Tooth and lip mutilation practices and associated tooth loss and oral mucosal lesions in the Makonde people of southeast Tanzania. East African Medical Journal. Nairobi, 84 (4):183-7.

FREYRE, G.

1957 Deformações de Corpo dos Negros Fugidos. In: Carneiro, E. (Org.) Antologia do Negro Brasileiro. Rio de Janeiro, Tecnoprint Gráfica S.A.: 183-186.

FLORENTINO, M.G.

2002 Em Costas Negras: uma História do Tráfico de Escravos entre a África e o Rio de Janeiro. São Paulo: Companhia das Letras.

HALESTRAP, D.J.

1971 Indigenous dental practice in Uganda. Bri tish Dental Journal. London, 131: 463-464.

HANDLER, J.S.

1994 Determining African birth from skeletal remains: a note on tooth mutilation. Historical Archaeology, Stone Mountain, 28 (3):113-119.

HANDLER, J.S., CORRUCCINI, R.S.; MUTAW, R.J.

1982 Tooth mutilation in the Caribbean: evidence from a slave burial population in Barbados. Journal of Human Evolution, 11: 297-313.

HILLSON, S.

1996 Dental Anthropology. Cambridge: Cambridge University Press.

JONES, A.

1992 Tooth mutilation in Angola. British Dental Journal. London, 173:176-179.
KABIRU, A.

2009 The practice of tooth extraction. Kenya Past and Present. Nairobi, 38:25-32.

LIMA, P.E.

1954 Deformações Tegumentares e Mutilação

Dentária entre os Índios Tenetehára. Boletim do Museu Nacional. Rio de Janeiro, Oficina Gráfica da Universidade do Brasil, 16: 1-22.

LIRYO, A.

2003 Lesões Dentárias em Esqueletos do Sítio Arqueológico Igreja da Sé, Dissertação de Mestrado, NESC/UFRJ.

LIRYO, A., CARVALHO, D.M. DE, SOUZA, S.M. DE

2004 Saúde dentária dos escravos em Salvador, Bahia. In: Nascimento, D.R.; Carvalho, D.M. (Orgs.) Uma história brasileira das doenças. Brasília, Paralelo 15: 232-242.

LIRYO, A.; RODRIGUES-CARVALHO, C.; SOUZA, S.M. DE; CARVALHO, D.M.

2001 Modificações Dentárias na Primeira Catedral do Brasil, Salvador, Bahia. Antropologia Portuguesa. Coimbra, 18 (1): 119-141.

MACHADO, L.C.

2006 O Sítio Cemitério dos Pretos Novos, Análise Biocultural. Interpretando os Ossos e os Dentes Humanos. Boletim do Instituto de Arqueologia Brasileira, 12: 1-24.

MORRIS, A.G.

1998 Dental Mutilation in Southern African History and Prehistory with Reference to the "Cape Flats smile". South African Dental Association J. Apr, 53 (4):179-83.

NETTO, L.

1882 Do Corte Artificial dos Dentes. Revista da Exposição Anthropologica Brazileira. Rio de Janeiro, Museu Nacional: 46-47.

NESI, W.

1968 Mutilação Dentária em Silvícolas de Roraima. Arquivos Fluminenses de Odontologia, 1 (3): 8-14.

1969 Contribuição ao Estudo das mutilações Dentárias: aspectos patológicos. In: Cunha, E. de M.S. (Org.) Anais da Sétima Jornada Fluminense de Odontologia "Prof. Coelho e Souza" da Faculdade de Odontologia/Universidade Federal Fluminense: $38-49$.

NESI, W.; QUEIROZ, V.

1968 Mutilações Dentárias. In: Cunha, E. de M.S. (Org.) Anais da Sexta Jornada Fluminense de Odontologia "Prof. Coelho e Souza". Faculdade de Odontologia /Universidade Federal Fluminense: 67-70. 
ORTIZ, F.

1929 Los Afrocubanos dientimellados. Archivos del Folklore Cubano, 4:16-29.

ORTNER, D.

1966 A recent occurrence of an African type tooth mutilation in Florida. American Journal of Physical Anthropology, 25: 177-180.

PEIXOTO, A.

1980 Breviário da Bahia. 3a ed. Rio de Janeiro: Ministério da Educação e Cultura/Conselho Federal de Cultura.

PEREIRA, J.C.M. DA S.

2007 À Flor da Terra: o Cemitério dos Pretos Novos no Rio de Janeiro. Rio de Janeiro: Garamond/Prefeitura do Rio de Janeiro.

PEREIRA FILHO, A.G.A.

1968 Mutilação dos Dentes. In: Cunha, E. de M.S. (Ed.) Anais da Academia Brasileira de Odontologia (Raridades Bibliográficas de Patronos da Academia): 178-180.

REIS, J.J.

1991 A Morte é Uma Festa: ritos fúnebres e revolta popular no Brasil do século XIX. 3a reimpressão. São Paulo: Companhia das Letras.

RODD, H.D.; DAVIDSON, L.E.

2000 'Ilko dacowo:' canine enucleation and dental sequelae in Somali children. International Journal of Paediatric Dentistry, 10: 290-297.

SANTOS, D.M.

1988 História de um Terreiro Nagô. São Paulo: Max Limonade.

SANTOS, J.N.R.

1962 Mutilações Dentárias em Pretos de Moçambique. Garcia de Orta, 10 (2): 263-282.

SCHWARCZ, L.M.

1996 Ser Peça, Ser Coisa: definições e especificidades da escravidão no Brasil. In: Schwarcz,
L. M.; Reis, L.V.S. (Orgs.) Negras Imagens: ensaio sobre cultura e escravidão no Brasil. São Paulo, EDUSP: 75-89.

SINGER, R.

1953 Artificial Deformation of Teeth: Preliminary Report. Suid-Afrikanese Joernaal van Welenskap, December: 116-122.

STEWART, T.D.; GROOME, J.R.

1968 The African custom of tooth mutilation in America. American Journal of Physical Anthropology, 28:31-42.

TAVARES, A.C.P.

2006 Vestígios Materiais nos Enterramentos na Antiga Sé de Salvador. Postura das Instituições Religiosas Africanas frente à Igreja Católica em Salvador no Período Escravista. Dissertação de Mestrado. UFPe/ CFCH-Programa de Pós-graduação em Arqueológicas.

TIESLER, V.

2002 New cases of an African tooth decoration from colonial Campeche, Mexico. Homo, 52 (3): 277-282.

VERGER, P.

1987 Fluxo e Refluxo do Tráfico de Escravos entre o Golfo do Benin e a baia de Todos os Santos do Século XVII ao XIX. São Paulo: Editora Corrupio Comércio Ltda.

VIANNA FILHO, L.

1946 O Negro na Bahia. São Paulo: Livraria José Olympio Editora.

WILSON, K.J.; CABAK, M.A.

2004 Feminine voices from beyond the grave: what burials can tell us about gender differences among historic African Americans. In: Galle, J.E.; Young, A.L. (Eds.) Engendering African-American Archaeology. A Southern Perspective. Knoxville, The University of Tennessee Press: 263-285. 